\title{
EI Niño-Southern Oscillation and water resources in the headwaters region of the Yellow River: links and potential for forecasting
}

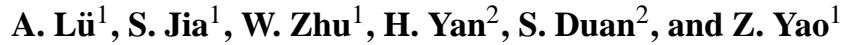 \\ ${ }^{1}$ Institute of Geographical Sciences and Natural Resources Research, Chinese Academy of Sciences, Beijing, 100101, China \\ ${ }^{2}$ Qinghai Hydrology and Water Resource Survey Bureau, Xining Qinghai, 810001, China
}

Received: 26 September 2010 - Published in Hydrol. Earth Syst. Sci. Discuss.: 27 October 2010

Revised: 16 March 2011 - Accepted: 15 April 2011 - Published: 21 April 2011

\begin{abstract}
This research explores the rainfall-El NiñoSouthern Oscillation (ENSO) and runoff-ENSO relationships and examines the potential for water resource forecasting using these relationships. The Southern Oscillation Index (SOI), Niño1.2, Niño3, Niño4, and Niño3.4 were selected as ENSO indicators for cross-correlation analyses of precipitation and runoff. There was a significant correlation $(95 \%$ confidence level) between precipitation and ENSO indicators during three periods: January, March, and from September to November. In addition, monthly streamflow and monthly ENSO indictors were significantly correlated during three periods: from January to March, June, and from October to December (OND), with lag periods between one and twelve months. Because ENSO events can be accurately predicted one to two years in advance using physical modeling of the coupled ocean-atmosphere system, the lead time for forecasting runoff using ENSO indicators in the Headwaters Region of the Yellow River could extend from one to 36 months. Therefore, ENSO may have potential as a powerful forecasting tool for water resources in the headwater regions of Yellow River.
\end{abstract}

\section{Introduction}

The El Niño-Southern Oscillation (ENSO) phenomenon is a natural part of the global climate system and results from the interaction between the oceans and the atmosphere that occur mainly across the tropical-subtropical Pacific region

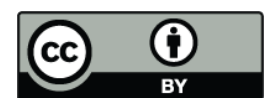

Correspondence to: S. Jia

(jiasf@igsnrr.ac.cn) to the Indian Ocean basin (Rasmusson and Carpenter, 1982; Kiladis and Diaz, 1989; Webster et al., 1998; Allan, 2000). Many studies have shown that the occurrence of an ENSO can result in climate variability (i.e., changes in wind, temperature, and precipitation) throughout the tropics and in broad swaths of the extratropics during the ENSO event or after a lag time of several months (Hamlet and Lettenmaier, 1999; Barton and Ramírez, 2004). The physical dynamics of ENSO are now reasonably well understood, and ENSO activity can be predicted one to two years in advance using several coupled ocean/atmosphere models (Barnston and Ropelewski, 1992; Piechota et al., 1997; Hamlet and Lettenmaier, 1999; Allan, 2000; Whitaker et al., 2001; Gutiérrez and Dracup, 2001). The delayed response of climate variability to ENSO and the overall predictability of ENSO make ENSO indicators a valuable predictor for regional climates because of the longer lead-time compared to other predictors.

There have been numerous studies examining the relationship between ENSO and rainfall (Ropelewski and Halpert, 1986, 1987; Chiew et al., 1998; Chandimala and Zubair, 2007). These studies showed that rainfall variability is significantly correlated with ENSO activity across different spatiotemporal scales. Therefore streamflow, as a comprehensive integrator of rainfall over large areas, may be related to ENSO. The ability to predict river flow patterns would be highly enhanced if a strong relationship between river discharge and ENSO can be demonstrated and quantified. Streamflow forecasting is vital for effective water resource management. Forecasting methods with longer lead-times will permit the reallocation of resources and the implementation of more efficient reservoir operation policies.

Published by Copernicus Publications on behalf of the European Geosciences Union. 


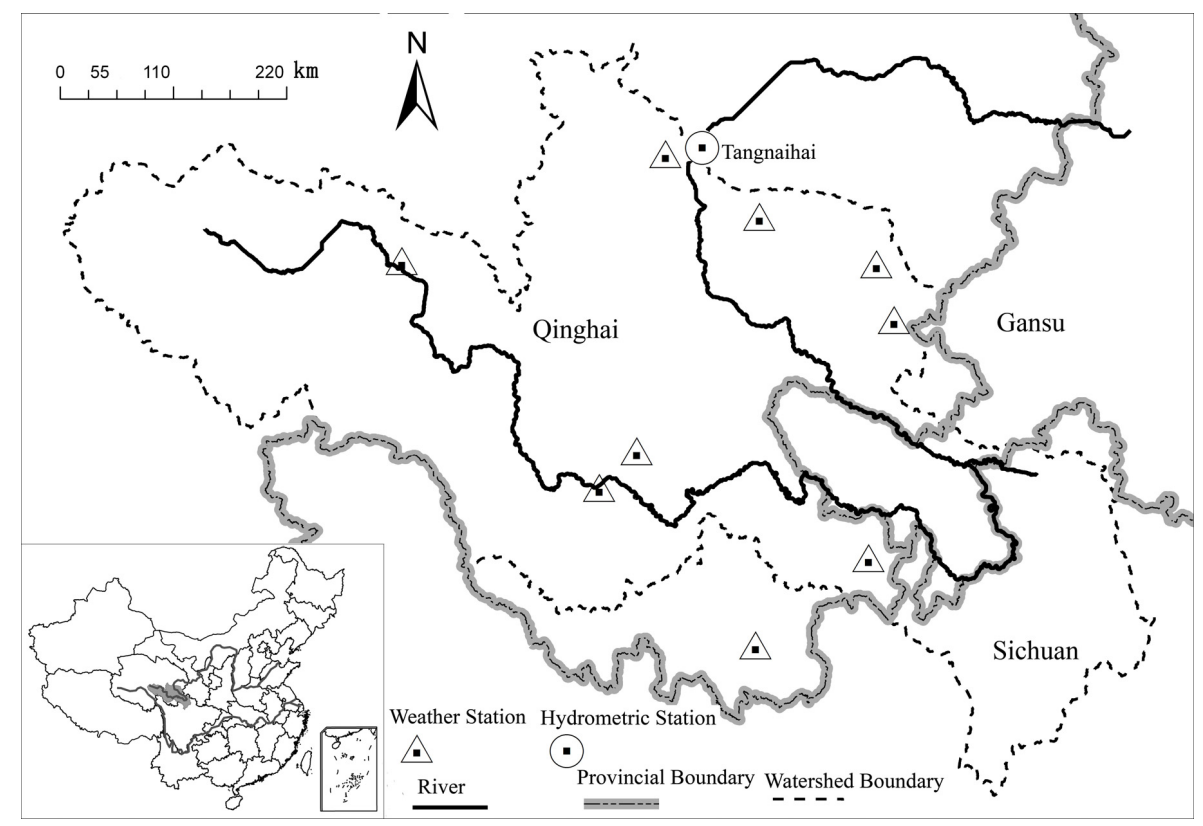

Fig. 1. The geographic location of Headwaters region of Yellow River and the location of hydrometric station used in this study.

During the past several years, there has been considerable interest in addressing the relationship between ENSO and the variability of streamflow at different spatial scales. Chiew and McMahon (2002) investigated the global ENSOstreamflow teleconnection by fitting a first harmonic to 24month El Nino streamflow composites from 581 catchments worldwide. The potential for forecasting was investigated by calculating the lagged correlation between streamflow and two indicators of ENSO in that study. At a regional scale, the ENSO-streamflow teleconnection has been studied in the United States (Redmond and Koch, 1991; Cayan et al., 1999; Piechota et al., 1997; Kahya and Dracup, 1993), Turkey (Kahya and Karabork, 2001), Australia (Simpson et al., 1993; Chiew et al., 1998), Sri Lanka (Zubair and Chandimala, 2006; Chandimala and Zubair, 2007), and Nepal (Shrestha and Kostaschuk, 2005). At a local scale, a significant relationship between ENSO indicators and the streamflow have been observed for a number of rivers, such as the Mississippi (Twine et al., 2005), Colombia (Gutiérrez and Dracup, 2001; Barton and Ramírez, 2004; Hamlet and Lettenmaier, 1999), Arizona's Salt River Basin (Karamouz and Zahraie, 2004), and the Ganges Rivers (Whitaker et al., 2001; Jahan et al., 2006).

In this analysis, we will look specifically at the Headwaters Region of the Yellow River (HRYR), located mostly in the Qinghai Province in western China (Fig. 1). The Yellow River is the second-longest river in China (and the sixthlongest in the world ) and is called "the cradle of Chinese civilization" because its basin is the birthplace of the northern Chinese civilizations and was the site of the most prosperous region in early Chinese history. In northern China, the Huanghe (Yellow River) is a major source of freshwater for the population of 107 million people who live within the river basin (Fig. 1), about $8.7 \%$ of the total population in China (Wang et al., 2006). The basin includes approximately 3.1 million hectares of irrigation area for agriculture, comprising $12.5 \%$ of the total agricultural irrigation area in China. The headwaters region of the Yellow River is the most important, as it generates $40 \%$ of the flow in the whole Yellow river system. Although many studies have qualitatively discussed the effect of ENSO on stream flow in the HRYR through analysis of the runoff difference between different ENSO phases (Wang et al., 2001, 2006; Lan et al., 2002), it is difficult to make long range forecasts based on ENSO indicators without constructing, testing, and quantifiying the relationship between periodical stream flow and ENSO indicators. In this study, we will try to define the relationship between monthly discharge in the HRYR and ENSO indicators. If feasible, using ENSO indicators to predicting streamflow with greater lead time would be valuable for water resource management.

In Sect. 2 we will describe the data and methods used in the analysis. In Sect. 3, the relationship between monthly discharge and ENSO indicators will be examined. To refine our understanding, two other relationships (monthly discharge and monthly precipitation, monthly precipitation and ENSO indicators) will also be examined. In Sect. 4, the main conclusions are summarized and their implications are discussed. 


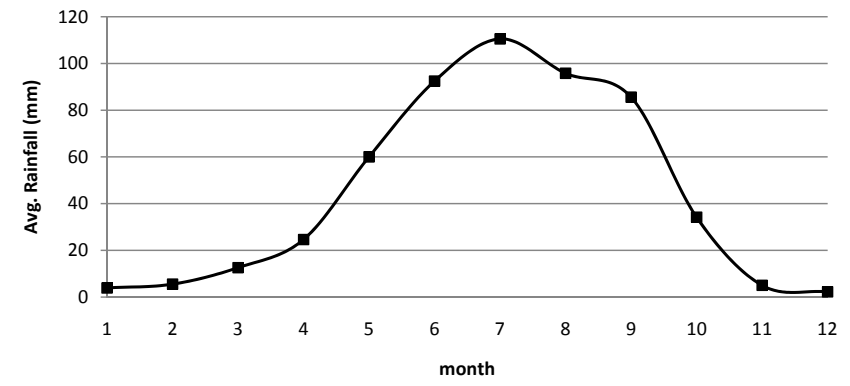

Fig. 2. Average monthly rainfall of headwaters region of the Yellow River.

\section{Data and methods}

\subsection{Description of the HRYR}

The HRYR is located in northeast of the Qinghai-Tibet Plateau and has a catchment area of approximatedly $12.3 \times 10^{4} \mathrm{~km}^{2}$. It stretches from longitude $95^{\circ} 50^{\prime} \mathrm{E}$ to $103^{\circ} 30^{\prime} \mathrm{E}$ and latitude from $32^{\circ} 10^{\prime} \mathrm{N}$ to $366 \circ 05^{\prime} \mathrm{N}$ and primarily lies in Qinghai Province with minor portions of the basin extending into two surrounding provinces (Sichuan and Gansu) (see Fig. 1).The elevation of the basin ranges from 2546 to $6282 \mathrm{~m}$ with an average elevation above $3000 \mathrm{~m}$. The estimated annual precipitation from 1959 to 2008 was $522 \mathrm{~mm}$ (Lan et al., 2010). The mean annual temperature was $0.26^{\circ} \mathrm{C}$ and the annual potential evapotranspiration ranges from 2000 to $1200 \mathrm{~mm}$ across the basin. The basin annual runoff is approximately $2 \times 10^{10} \mathrm{~m}^{3}$, and the average runoff depth is $164.5 \mathrm{~mm}$.

\subsection{Hydro climate data}

Fifty years (1956 to 2005) of continuous monthly streamflow data (Fig. 2) for this study were collected at the Tangnaihai Hydrometric Station $\left(100^{\circ} 09^{\prime} \mathrm{E}, 35^{\circ} 30^{\prime} \mathrm{N}\right)$ from a modified streamflow record database compiled by the Hydrology and Water Resource Surveying Bureau (HWRSB) of Qinghai Province. During periods when social and economic activities consume significant amounts of water of the river, the streamflow data measured at the hydrometric stations is usually lower than for natural runoff. For this study, the streamflow data has been modified by the HWRSB through addition of the volume of water consumed by daily life, industrial and agricultural production to the raw measurements from the hydrometric stations.

The climate data (1956 to 2005), which included monthly temperature and precipitation, were obtained from the China Meteorological Administrator via their website (http://cdc. cma.gov.cn/). Figures 3 and 4 show the average monthly precipitation and temperature, respectively. The maximum monthly precipitation in the HRYR occurs in July. Mean monthly precipitation is below $20 \mathrm{~mm}$ between January and March and between November and December each year.

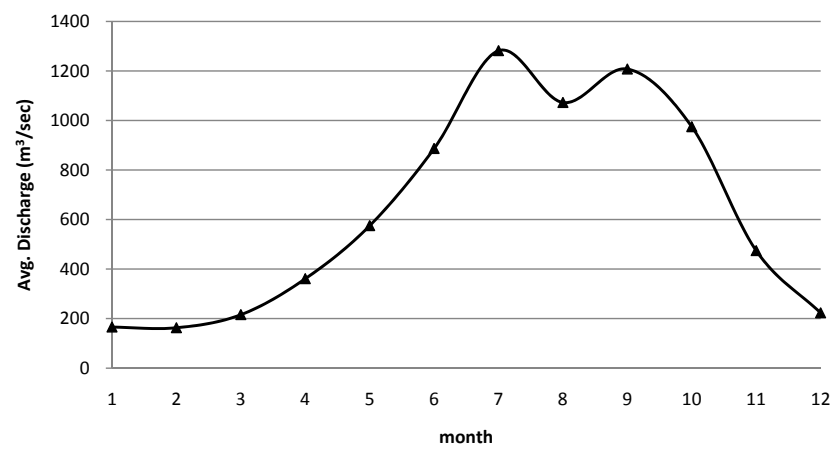

Fig. 3. Average monthly streamflow hydrographs of headwaters region of the Yellow River.

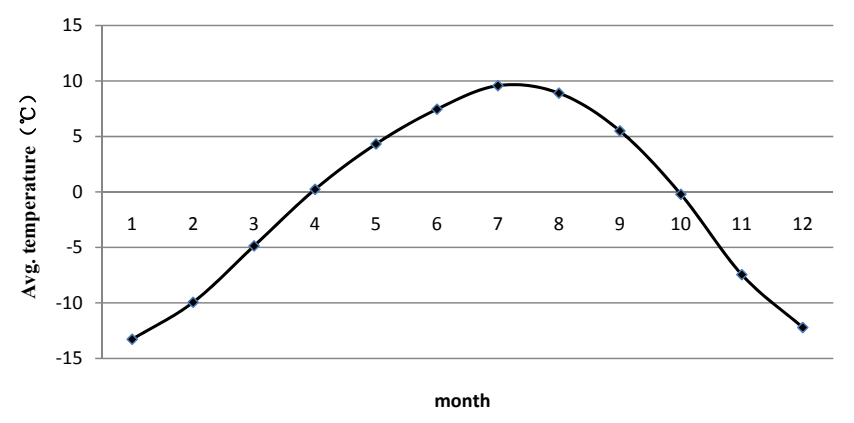

Fig. 4. Average monthly temperature of headwaters region of the Yellow River.

Mean monthly temperature is above zero from April and September and below zero for the rest of year.

\subsection{ENSO indicators}

The ENSO activity is typically monitored by observing the sea level pressures and Tropical Pacific Sea Surface Temperature (SST) in the equatorial Pacific. The ENSO indicators used in this study are the Southern Oscillation Index (SOI) and the SSTs in the three regions known as Niño1.2, Niño3, Niño4, and Niño3.4 (see Fig. 5).

The SOI is the most commonly used indicator to quantify the strength of an ENSO event and is computed as the normalized difference in standardized sea level pressure anomalies between Tahiti and Darwin relative to its root mean square (Troup, 1965). The monthly SOI data used in this study were retrieved from the Climate Prediction Centre of the US National Oceanic and Atmospheric Administration (CPC, NOAA) (http://www.cpc.noaa.gov/data/indices/ soi). The other indicators are the Niño1.2, Niño3, Niño4, and Niño3.4 SST anomalies in various equatorial Eastern Paci?c Ocean regions: Niño1.2 $\left(80^{\circ} \mathrm{W}-90^{\circ} \mathrm{W}, 10^{\circ} \mathrm{S}\right.$ to the equator), $\mathrm{Niño} 3\left(120^{\circ} \mathrm{W}-150^{\circ} \mathrm{W}, 5^{\circ} \mathrm{S}\right.$ to $\left.5^{\circ} \mathrm{N}\right)$, Niño3.4 $\left(120^{\circ} \mathrm{W}-\right.$ $170^{\circ} \mathrm{W}, 5^{\circ} \mathrm{S}$ to $\left.5^{\circ} \mathrm{N}\right)$ and Niño4 $\left(150^{\circ} \mathrm{W}-180^{\circ} \mathrm{W}, 5^{\circ} \mathrm{S}\right.$ to $5^{\circ} \mathrm{N}$ ) (see Fig. 5). Monthly data for these indicators can also 
Table 1. The correlations between monthly runoff and monthly precipitation with different lag month.

\begin{tabular}{|c|c|c|c|c|c|c|c|c|c|c|c|c|c|}
\hline Month & \multicolumn{13}{|c|}{ Lag (month) } \\
\hline Jan & 0.032 & -0.084 & 0.200 & 0.294 & 0.508 & 0.428 & 0.346 & 0.305 & 0.201 & 0.160 & -0.132 & -0.031 & -0.042 \\
\hline Mar & -0.084 & 0.267 & 0.019 & -0.155 & 0.156 & 0.257 & 0.433 & 0.379 & 0.273 & 0.218 & 0.301 & 0.153 & -0.119 \\
\hline Apr & 0.100 & 0.249 & 0.314 & 0.357 & -0.204 & 0.127 & 0.110 & 0.194 & 0.320 & 0.036 & 0.198 & 0.080 & -0.012 \\
\hline May & 0.217 & 0.289 & 0.186 & 0.310 & 0.113 & -0.149 & 0.120 & 0.033 & 0.356 & 0.350 & 0.114 & 0.051 & 0.154 \\
\hline Aug & 0.400 & 0.650 & 0.181 & 0.232 & -0.145 & -0.128 & 0.094 & -0.007 & -0.066 & 0.204 & 0.274 & 0.194 & -0.109 \\
\hline Sep & 0.654 & 0.580 & 0.291 & 0.083 & 0.163 & 0.064 & -0.041 & -0.222 & -0.086 & -0.109 & 0.186 & -0.043 & 0.216 \\
\hline Oct & 0.437 & 0.630 & 0.346 & 0.294 & 0.149 & 0.043 & 0.178 & -0.064 & -0.195 & -0.017 & 0.008 & 0.103 & -0.058 \\
\hline Nov & 0.179 & 0.564 & 0.428 & 0.411 & 0.295 & 0.199 & 0.067 & 0.145 & -0.046 & -0.066 & 0.051 & 0.004 & 0.052 \\
\hline Dec & -0.103 & 0.125 & 0.415 & 0.455 & 0.448 & 0.379 & 0.200 & 0.173 & 0.153 & -0.091 & -0.027 & -0.006 & -0.008 \\
\hline
\end{tabular}

Note: Significant correlation at $95 \%$ confidence level are shown with bold fonts.

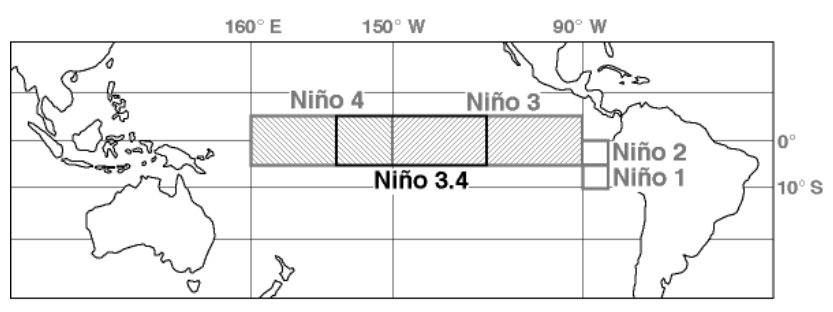

Fig. 5. SST regions (referred to Niño1.2, Niño3, Niño4, and Niño3.4) monitoring ENSO conditions.

be obtained from the CPC database (http://www.cpc.noaa. gov/data/indices/).

\subsection{Methods}

To determine the relationship between ENSO indicators and the monthly steamflow and rainfall of the HRYR and the feasibility of using this relationship to forecast monthly water resources, the following unknowns had to be determined: (1) which ENSO indicator(s) has the best correlation with each month's streamflow and rainfall; (2) which monthly indicator has the best correlation; and (3) the lead-time or lag for this relationship.

To determine the unknowns described above, crosscorrelation analyses were performed for each month's streamflow and ENSO indicators with different lag periods using Pearson's correlation coefficient, a linear measure (Press et al., 1992). A correlation was taken to be significant when the hypothesis that there was no correlation between two time-series was unlikely with a probability of $95 \%$ and highly significant when the probability was $99 \%$. Lag-zero to lag- twelve were used, with the "lag- $n$ " correlation defined as the significant correlation that can be obtained using indicators from $n$ months prior.

\section{Results and discussion}

\subsection{Precipitation-discharge relationships}

Many studies have demonstrated that ENSO-driven precipitation fluctuations translate into significant variation of streamflow in several regions (Cayan et al., 1999; Kahya and Dracup, 1993, 1994; Kazadi and Kaoru, 1996; Marengo et al., 1998). Therefore, to better understand the relationship between ENSO and monthly streamflow in the HRYR, the relationship between monthly precipitation and monthly discharge was examined first (Table 1).

Discharge in January, February, and March (JFM) was mainly affected by the precipitation in June, July, August, September, and October (JJASO) of the previous year. In spring, snow is the primary form of precipitation, with less streamflow discharge generated because the average monthly temperature is below zero (Fig. 4). During this period, therefore, base flow accounted for the most of the monthly discharge in the HRYR (Liang et al., 2008). June, July, and August are the rainy season in the HRYR and an important period for ground water recharge (Fig. 3). With less but continuous rainfall, September and October are also a valuable period for ground water recharge (Chang et al., 2007). The analysis above shows that the precipitation in JJASO of the previous year affects spring discharge through altering the base flow and contributing to the variation in ground water stores.

In April and May, snowmelt becomes an important component of streamflow as the average monthly temperature rises above zero. During this period, the streamflow is drawn from three sources: snowmelt, rainfall, and base flow. Streamflow in April is significantly correlated with both the precipitation in August of the previous year and precipitation in January and February of current year. Streamflow in May was statistically correlated (95\% confidence level) 
with precipitation during August and September of the previous year and February and April's precipitation in the current year. In this period, the previous year's precipitation (in August and September) could affect the base flow through recharging of the ground water. Precipitation in January and February contributed the accumulation of snow and affected the volume of snowmelt runoff.

In June, streamflow was correlated with the level of June precipitation at a $95 \%$ confidence level. It also was significantly correlated with precipitation in April and precipitation in October of the previous year. This indicates that streamflow in June is affected by precipitation during the current and previous months as well as base flow.

During July, August, and September (JAS), streamflow achieved the highest levels of the year. Streamflow during JAS was not only correlated with the precipitation of the current month, but it also correlated with precipitation of the previous one or two months. Higher intensity and more concentrated precipitation generates surface runoff during this period (Chang et al., 2007). The precipitation of the previous 1 to 2 months impacts monthly streamflow mainly by altering soil moisture and groundwater storage.

For the period of October, November, and December (OND), streamflow decreased along with the significant reduction in precipitation. Base flow accounted for the majority of runoff during OND. The precipitation of previous months could affect runoff of OND greatly through recharging of groundwater. Correlation analysis showed that streamflow during OND was significantly correlated with the precipitation of July, August, September, and October at a 95\% confidence level.

\subsection{ENSO-precipitation relationships}

Many studies have examined the teleconnection between ENSO and precipitation throughout the tropics and in broad swaths of the extratropical regions (Ropelewski and Halpert, 1986, 1987, 1989; Chiew et al., 1998; Chandimala and Zubair, 2007). In this section, using historical monthly precipitation data (1956 to 2005) and ENSO indicator data (SOI, Niño1.2, Niño3, Niño4, and Niño3.4 from 1955 to 2005), the correlation between monthly precipitation of the HRYR and ENSO indicators were examined (Table 2).

Significant correlations (95\% confidence level) were found during three periods: January, March, and from September to November (Table 2). In January, lag-three and lag-nine precipitation-SOI were significantly correlated at the $95 \%$ confidence level. Both monthly Niño3 and Niño3.4 were significantly correlated with precipitation in January with continuous lag months (Table 2). Precipitation in March was significantly correlated with all the ENSO indicators except Niño1.2 with different lag periods, from lag-zero to lageleven. Further analysis showed that there were significant correlations with continuous lag periods from a short lag period to longer periods for Niño4 at $90 \%$ confidence level (Table 2).

In September, the precipitation was only correlated with Niño3 ( $r=-0.317$ with lag-seven) and Niño1.2 $(r=-0.476$ with lag-seven and $r=-0.370$ with lag-eight) at a $95 \%$ confidence level. Significant correlations with continuous lag periods were found in OND. In October, the precipitation was significantly correlated with monthly SOI and Niño3 for lag periods from zero to three months and had significant correlations with monthly Niño4 and Niño3.4 with lag periods from zero to four months. There was significant correlation between precipitation in November and monthly ENSO indicators for longer lag periods, from six to twelve months for Niño3, Niño4, and Niño3.4 and from eight to twelve months for SOI and Niño1.2.

\subsection{ENSO-discharge relationships}

There were significant correlations between monthly streamflow and monthly ENSO indictors during three periods: JFM, June, and OND, and no significant correlations were detected during other periods (Table 3).

During JFM, streamflow was positively correlated with SOI and negatively correlated Niño4 with different lag periods at the $95 \%$ confidence level. The significant correlation between streamflow in January and monthly Niño4 was continuously significant from lag-one to lag-twelve and achieved the highest correlation efficiency $(r=-0.418)$ at lag-five month. Significant streamflow-Niño4 correlations in February were found between lag-two and lag-eight and achieved the highest correlation efficiency $(r=-0.437)$ at lag-six month. Streamflow in March had significant correlations with Niño4 with lag periods from lag-two to lag-nine and achieved the highest correlation efficiency $(r=-0.448)$ at lag-seven month. Further analyses showed that monthly streamflow in JFM had the strongest correlation with the Niño4 of the previous autumn. Monthly streamflow in JFM was also significantly correlated with periodical SOI from April to September of the previous year. The correlation efficiency of streamflow-SOI in March was higher than that of January and February. Comparison of the correlation between streamflow-SOI and streamflow-Niño4 showed that streamflow-Niño4 correlation had a higher correlation coefficient and a longer lag period than streamflow-SOI.

In June, streamflow was negatively correlated with SOI, Niño4, and Niño3.4 at a 95\% confidence level (Table 3). Lag correlation analysis showed that streamflow in June was significantly correlated with Niño4 for lag periods from two to eleven months and earned the highest correlation efficiency $(r=-0.459)$ with Niño4 from four months prior, i.e., the previous December. The streamflow-Niño3.4 correlation was also significant between lag-three to lag-eleven months and achieved highest correlation efficiency $(r=-0.377)$ at lageight month. 
Table 2. The correlations between monthly precipitation and monthly ENSO indicators with different lag month.

\begin{tabular}{|c|c|c|c|c|c|c|c|c|c|c|c|c|c|c|}
\hline \multirow[t]{2}{*}{ Month } & \multirow{2}{*}{$\begin{array}{l}\text { ENSO } \\
\text { indicator }\end{array}$} & \multicolumn{13}{|c|}{ Lag (Month) } \\
\hline & & 0 & 1 & 2 & 3 & 4 & 5 & 6 & 7 & 8 & 9 & 10 & 11 & 12 \\
\hline \multirow[t]{5}{*}{ Jan } & soi & -0.064 & -0.010 & -0.028 & -0.318 & -0.103 & -0.186 & -0.126 & -0.284 & 0.016 & -0.303 & -0.259 & -0.133 & -0.262 \\
\hline & nino3 & -0.034 & -0.020 & -0.019 & -0.022 & 0.022 & 0.022 & 0.052 & 0.237 & 0.421 & 0.483 & 0.268 & 0.214 & 0.129 \\
\hline & nino4 & 0.025 & 0.055 & 0.066 & 0.063 & 0.179 & 0.158 & 0.243 & 0.238 & 0.218 & 0.228 & 0.186 & 0.130 & 0.120 \\
\hline & nino12 & -0.126 & -0.014 & -0.005 & 0.061 & 0.055 & 0.069 & 0.079 & 0.159 & 0.238 & 0.253 & 0.200 & 0.236 & 0.146 \\
\hline & $\operatorname{nino} 34$ & -0.004 & -0.014 & -0.005 & -0.023 & 0.064 & 0.040 & 0.122 & 0.253 & 0.429 & 0.448 & 0.269 & 0.194 & 0.130 \\
\hline \multirow[t]{5}{*}{ Mar } & soi & -0.434 & -0.400 & -0.198 & -0.285 & -0.250 & -0.324 & -0.303 & -0.384 & -0.265 & -0.204 & -0.302 & -0.367 & -0.120 \\
\hline & nino3 & 0.301 & 0.288 & 0.270 & 0.307 & 0.336 & 0.344 & 0.346 & 0.228 & 0.279 & 0.321 & 0.291 & 0.178 & 0.227 \\
\hline & nino4 & 0.316 & 0.269 & 0.327 & 0.346 & 0.287 & 0.304 & 0.361 & 0.302 & 0.355 & 0.363 & 0.365 & 0.348 & 0.276 \\
\hline & nino12 & 0.085 & 0.255 & 0.236 & 0.219 & 0.257 & 0.292 & 0.180 & 0.087 & 0.128 & 0.177 & 0.156 & 0.156 & 0.194 \\
\hline & nino34 & 0.330 & 0.256 & 0.275 & 0.318 & 0.313 & 0.323 & 0.358 & 0.267 & 0.317 & 0.369 & 0.342 & 0.262 & 0.225 \\
\hline \multirow[t]{5}{*}{ Sep } & soi & 0.161 & 0.234 & 0.168 & 0.117 & 0.150 & 0.243 & 0.181 & 0.138 & 0.083 & -0.017 & 0.038 & 0.111 & 0.094 \\
\hline & nino3 & -0.090 & -0.116 & -0.082 & -0.129 & -0.197 & -0.234 & -0.266 & -0.317 & -0.217 & -0.161 & -0.174 & -0.135 & -0.141 \\
\hline & nino4 & -0.097 & -0.077 & -0.095 & -0.155 & -0.120 & -0.145 & -0.129 & -0.124 & -0.145 & -0.104 & 0.009 & -0.004 & 0.011 \\
\hline & nino12 & -0.179 & -0.199 & -0.150 & -0.210 & -0.191 & -0.101 & -0.227 & -0.476 & -0.370 & -0.308 & -0.229 & -0.224 & -0.161 \\
\hline & nino34 & -0.081 & -0.072 & -0.067 & -0.146 & -0.202 & -0.273 & -0.212 & -0.226 & -0.181 & -0.119 & -0.122 & -0.075 & -0.094 \\
\hline \multirow[t]{5}{*}{ Oct } & soi & 0.399 & 0.465 & 0.355 & 0.392 & 0.115 & 0.412 & 0.292 & 0.010 & -0.097 & -0.016 & 0.101 & 0.098 & -0.040 \\
\hline & nino3 & $-\mathbf{0 . 5 0 7}$ & -0.438 & -0.311 & -0.304 & -0.237 & -0.112 & -0.045 & 0.025 & 0.111 & 0.124 & 0.156 & 0.133 & 0.149 \\
\hline & nino4 & -0.530 & -0.487 & -0.466 & -0.422 & -0.353 & -0.285 & -0.288 & -0.209 & -0.162 & -0.124 & -0.017 & -0.020 & 0.024 \\
\hline & nino12 & -0.317 & -0.253 & -0.136 & -0.088 & -0.099 & -0.038 & -0.094 & -0.050 & 0.097 & 0.169 & 0.212 & 0.218 & 0.226 \\
\hline & nino34 & -0.550 & $-\mathbf{0 . 4 9 7}$ & -0.450 & -0.431 & -0.362 & -0.206 & -0.145 & -0.055 & 0.004 & 0.041 & 0.088 & 0.083 & 0.134 \\
\hline \multirow[t]{5}{*}{ Nov } & soi & -0.047 & 0.041 & 0.122 & 0.086 & 0.075 & 0.069 & 0.080 & 0.262 & 0.306 & 0.349 & 0.321 & 0.333 & 0.342 \\
\hline & nino3 & -0.019 & -0.044 & -0.097 & -0.142 & -0.173 & -0.271 & -0.327 & -0.415 & -0.404 & -0.401 & -0.396 & -0.383 & -0.387 \\
\hline & nino4 & -0.071 & -0.074 & -0.129 & -0.151 & -0.208 & -0.252 & -0.320 & -0.381 & -0.429 & -0.418 & -0.376 & -0.305 & -0.262 \\
\hline & nino12 & -0.034 & -0.138 & -0.178 & -0.210 & -0.186 & -0.266 & -0.237 & -0.180 & -0.292 & -0.343 & -0.371 & -0.410 & -0.391 \\
\hline & $\operatorname{nino} 34$ & 0.000 & -0.006 & -0.051 & -0.049 & -0.108 & -0.235 & -0.352 & -0.472 & -0.436 & -0.427 & -0.396 & -0.349 & -0.342 \\
\hline \multirow[t]{5}{*}{ Dec } & soi & -0.291 & -0.261 & -0.250 & -0.190 & -0.324 & -0.178 & -0.328 & -0.195 & -0.100 & -0.038 & 0.324 & 0.103 & 0.119 \\
\hline & nino3 & 0.298 & 0.305 & 0.303 & 0.306 & 0.274 & 0.272 & 0.189 & 0.076 & -0.014 & -0.085 & -0.110 & -0.165 & -0.155 \\
\hline & nino4 & 0.212 & 0.195 & 0.183 & 0.248 & 0.223 & 0.188 & 0.095 & -0.045 & -0.073 & -0.172 & -0.185 & -0.152 & -0.216 \\
\hline & nino12 & 0.349 & 0.354 & 0.307 & 0.304 & 0.229 & 0.223 & 0.149 & 0.038 & 0.132 & 0.063 & -0.019 & -0.070 & -0.055 \\
\hline & nino34 & 0.234 & 0.247 & 0.243 & 0.302 & 0.285 & 0.250 & 0.150 & 0.024 & -0.123 & -0.171 & -0.185 & -0.195 & -0.214 \\
\hline
\end{tabular}

Note: Significant correlation at $95 \%$ confidence level are shown with bold fonts.

During OND, all ENSO indicators except Niño1.2 were significantly correlated with monthly streamflow. Streamflow during October was both positively correlated with monthly SOI and negatively correlated with monthly Niño4 and Niño3.4 at a $95 \%$ confidence level for lag periods between one and three months. In other words, the streamflow during October was significantly correlated with the monthly SOI, Niño4, and Niño3.4 values from September, August, and July at a 95\% confidence level. Streamflow during OND was positively correlated with the monthly SOI of September, August, and July at a 95\% confidence level (Table 3). Among these indicators, SOI had a longer lag period than the others and Niño4 had the highest correlation efficiency. Streamflow in OND was also significantly correlated with the monthly SOI, Niño3, Niño4, and Niño3.4 of September, August, and July (Table 3).

During JFM, SOI and Niño4 had significant correlations with runoff, while in June and October, Niño3.4 also had significant correlation with runoff except for SOI and Niño4. All indicators except Niño1.2 were significantly correlated with the monthly runoff of OND. Using different indicators to represent ENSO activity produced different results when we tried to define the relationship between runoff variation and ENSO activity. Beebee and Manga (2004) also found this difference when they examined the relationship between snowmelt runoff in Oregon and ENSO.

Comprehensive analysis of the precipitation-runoff (Table 1), precipitation-ENSO (Table 2), and runoff-ENSO (Table 3) correlations indicated that the months in which runoff was not significantly correlated with ENSO indicators was mainly due to periodical precipitation which was not significantly correlated with ENSO. For example, runoff in May was significantly correlated with rainfall during February (Table 1), whereas the rainfall of February was not significantly correlated with ENSO indicators (Table 2). Thus, the correlation between runoff in May and ENSO indicators was not significant at $95 \%$ confidence level. 
Table 3. The correlations between monthly streamflow and monthly ENSO indicators with different lag month.

\begin{tabular}{|c|c|c|c|c|c|c|c|c|c|c|c|c|c|}
\hline \multirow[t]{2}{*}{ Month } & \multirow{2}{*}{$\begin{array}{l}\text { ENSO } \\
\text { indicator }\end{array}$} & \multicolumn{12}{|c|}{ Lag (Month) } \\
\hline & & 1 & 2 & 3 & 4 & 5 & 6 & 7 & 8 & 9 & 10 & 11 & 12 \\
\hline \multirow[t]{5}{*}{ Jan } & soi & 0.066 & -0.019 & 0.126 & 0.284 & 0.297 & 0.276 & 0.256 & 0.346 & 0.289 & 0.049 & 0.121 & -0.006 \\
\hline & nino3 & -0.178 & -0.203 & -0.222 & -0.133 & -0.076 & -0.059 & -0.065 & -0.102 & -0.087 & -0.170 & -0.112 & -0.090 \\
\hline & nino4 & -0.277 & -0.326 & -0.334 & -0.399 & -0.418 & -0.371 & $-\mathbf{0 . 3 2 7}$ & -0.270 & -0.304 & -0.240 & -0.282 & -0.310 \\
\hline & nino12 & -0.107 & -0.134 & -0.154 & -0.019 & 0.077 & 0.115 & 0.025 & -0.039 & 0.019 & -0.088 & -0.081 & -0.037 \\
\hline & nino34 & -0.204 & -0.235 & -0.261 & -0.227 & -0.206 & -0.216 & -0.217 & -0.193 & -0.216 & -0.177 & -0.161 & -0.156 \\
\hline \multirow[t]{5}{*}{ Feb } & soi & -0.122 & 0.068 & 0.047 & 0.156 & 0.344 & 0.305 & 0.280 & 0.256 & 0.323 & 0.233 & -0.044 & 0.028 \\
\hline & nino3 & 0.031 & -0.203 & -0.217 & -0.235 & -0.130 & -0.073 & -0.043 & -0.023 & -0.003 & 0.050 & -0.034 & 0.029 \\
\hline & nino4 & -0.248 & -0.335 & -0.384 & -0.391 & -0.417 & $-\mathbf{0 . 4 3 7}$ & -0.380 & -0.306 & -0.261 & -0.279 & -0.197 & -0.220 \\
\hline & nino12 & 0.133 & -0.109 & -0.142 & -0.136 & 0.012 & 0.131 & 0.175 & 0.113 & 0.065 & 0.155 & 0.047 & 0.076 \\
\hline & nino34 & -0.054 & -0.253 & -0.276 & -0.305 & -0.251 & -0.232 & -0.236 & -0.202 & -0.120 & -0.133 & -0.082 & -0.048 \\
\hline \multirow[t]{5}{*}{ Mar } & soi & 0.183 & 0.181 & 0.113 & 0.085 & 0.200 & 0.379 & 0.356 & 0.264 & 0.266 & 0.335 & 0.190 & 0.075 \\
\hline & nino3 & -0.194 & -0.237 & -0.253 & -0.259 & -0.264 & -0.139 & -0.087 & -0.077 & -0.083 & -0.066 & -0.011 & -0.029 \\
\hline & nino4 & -0.270 & -0.310 & -0.331 & -0.391 & -0.393 & -0.436 & -0.448 & -0.391 & -0.311 & -0.243 & -0.230 & -0.125 \\
\hline & nino12 & -0.124 & -0.115 & -0.184 & -0.197 & -0.176 & -0.041 & 0.077 & 0.149 & 0.078 & 0.049 & 0.102 & 0.000 \\
\hline & nino34 & -0.213 & -0.266 & -0.277 & -0.298 & -0.314 & -0.248 & -0.238 & -0.248 & -0.236 & -0.165 & -0.134 & -0.034 \\
\hline \multirow[t]{5}{*}{ June } & & 0.170 & 0.239 & 0.123 & 0.099 & 0.308 & 0.171 & 0.222 & 0.211 & 0.346 & 0.321 & 0.272 & 0.126 \\
\hline & nino3 & -0.029 & -0.123 & -0.195 & -0.166 & -0.241 & -0.264 & -0.273 & -0.316 & -0.250 & -0.252 & -0.245 & -0.167 \\
\hline & nino4 & -0.252 & -0.357 & -0.395 & -0.459 & -0.449 & -0.398 & -0.424 & -0.401 & -0.317 & -0.372 & -0.297 & -0.142 \\
\hline & nino12 & -0.069 & -0.011 & 0.005 & 0.040 & -0.082 & -0.160 & -0.185 & -0.193 & -0.159 & -0.072 & -0.012 & 0.005 \\
\hline & nino34 & -0.150 & -0.281 & -0.292 & -0.316 & -0.349 & $-\mathbf{0 . 3 3 2}$ & $-\mathbf{0 . 3 5 0}$ & $-\mathbf{0 . 3 7 7}$ & -0.292 & -0.348 & -0.347 & -0.240 \\
\hline \multirow[t]{5}{*}{ Oct } & soi & 0.384 & 0.358 & 0.290 & 0.255 & 0.277 & 0.243 & 0.004 & -0.103 & -0.090 & -0.072 & -0.190 & -0.096 \\
\hline & nino3 & -0.233 & -0.167 & -0.146 & -0.087 & -0.066 & 0.004 & -0.022 & 0.029 & 0.107 & 0.163 & 0.133 & 0.155 \\
\hline & nino4 & -0.426 & -0.405 & $-\mathbf{0 . 3 3 3}$ & -0.236 & -0.174 & -0.176 & -0.055 & -0.063 & -0.077 & -0.015 & 0.033 & 0.058 \\
\hline & nino12 & -0.144 & -0.040 & 0.012 & -0.035 & -0.038 & -0.033 & -0.142 & -0.108 & 0.066 & 0.093 & 0.140 & 0.088 \\
\hline & nino34 & $-\mathbf{0 . 3 2 0}$ & -0.293 & -0.296 & -0.225 & -0.146 & -0.101 & -0.005 & 0.013 & 0.052 & 0.116 & 0.095 & 0.147 \\
\hline \multirow[t]{5}{*}{ Nov } & soi & 0.250 & 0.447 & 0.396 & 0.389 & 0.310 & 0.344 & 0.281 & 0.008 & -0.074 & -0.050 & -0.007 & -0.150 \\
\hline & nino3 & -0.403 & -0.303 & -0.219 & -0.201 & -0.136 & -0.103 & -0.033 & -0.031 & 0.055 & 0.101 & 0.149 & 0.115 \\
\hline & nino4 & -0.489 & -0.511 & -0.499 & -0.431 & -0.307 & -0.241 & -0.257 & -0.124 & -0.128 & -0.143 & -0.062 & -0.043 \\
\hline & nino12 & -0.291 & -0.167 & -0.046 & 0.013 & -0.031 & -0.043 & -0.035 & -0.117 & -0.005 & 0.112 & 0.121 & 0.166 \\
\hline & nino34 & -0.453 & -0.403 & -0.366 & -0.372 & -0.288 & -0.194 & -0.153 & -0.045 & -0.004 & 0.022 & 0.082 & 0.056 \\
\hline \multirow[t]{5}{*}{ Dec } & soi & 0.056 & 0.210 & 0.388 & 0.354 & 0.396 & 0.330 & 0.339 & 0.295 & 0.018 & -0.037 & -0.016 & -0.025 \\
\hline & nino3 & -0.311 & $-\mathbf{0 . 3 3 7}$ & -0.240 & -0.181 & -0.147 & -0.141 & -0.154 & -0.084 & -0.094 & 0.002 & 0.046 & 0.097 \\
\hline & nino4 & $-\mathbf{0 . 4 3 0}$ & -0.418 & -0.453 & -0.456 & -0.401 & -0.309 & -0.262 & -0.276 & -0.139 & -0.148 & -0.167 & -0.101 \\
\hline & nino12 & -0.220 & -0.253 & -0.108 & -0.011 & 0.028 & -0.051 & -0.104 & -0.063 & -0.146 & -0.036 & 0.091 & 0.093 \\
\hline & nino34 & -0.364 & -0.391 & -0.344 & -0.322 & -0.315 & -0.285 & -0.232 & -0.200 & -0.087 & -0.046 & -0.029 & 0.033 \\
\hline
\end{tabular}

Note: Significant correlation at 95\% confidence level are shown with bold fonts.

\subsection{Potential for forecasting water resources in the HRYR using ENSO indicators}

Cross-correlation analysis showed that precipitation and runoff in the headwater regions of the Yellow River were significantly correlated with different ENSO indicator during the three periods (Tables 2 and 3) of JFM, June, and ODN. It also showed that the correlations have different lag periods, between one and twelve months. In other words, ENSO indicator period ends one to twelve months before the streamflow period. Recent studies indicate that ENSO events can be accurately predicted one to two years in advance using a physical model of the coupled ocean-atmosphere system (Cane et al., 1986; Barnston and Ropelewski, 1992; Chen et al.,
1995; Piechota et al., 1997; Whitaker et al., 2001; Gutiérrez and Dracup, 2001). In such instances, the lead time for forecasting runoff using ENSO in the Headwaters Region of the Yellow River can be extended from one to thirty-six months. Therefore, ENSO holds potential as a powerful forecasting tool for water resources in the headwater regions of the Yellow River.

JFM and ODN are the dry seasons in the headwater region of the Yellow River. The water demand of the lower reaches of the Yellow River in the dry season is more crucial than that of the wet season, as runoff in the dry season with low discharge usually constrains the industrial and agricultural development of these regions. Therefore, forecasting of JFM and ODN runoff using the ENSO indicators examined in this 
study will be very important for water management in the lower reaches of the Yellow River.

\section{Conclusion and perspective}

The analyses show that rainfall during three periods (January, March, and from September to November) was significantly correlated with ENSO indicators at a 95\% confidence level with lag periods from zero to twelve months. This investigation demonstrates that there were significant correlations between monthly streamflow and monthly ENSO indictors during three periods (JFM, June, and OND) and no significant correlations were detected during other periods. Time lagged correlation between ENSO indicators, rainfall and runoff suggest that ENSO indicators can be used with some success to forecast rainfall and runoff in the headwater region of the Yellow River several months in advance.

Although this study establishes statistical links between the El Niño-Southern Oscillation and observed streamflow in the headwater region of the Yellow River, further research on the physical mechanisms driving these relationships is needed. Thus, comprehensive water balance studies are required to determine the source of atmospheric moisture and precipitation as well as factors governing evapotranspiration following ENSO activities. Future studies are necessary to better understand the role of ENSOs in the global hydrologic cycle and their potential future state using coupled atmospheric/oceanic/land surface models.

Acknowledgements. This study was supported and funded by National Basic Research Program of China (Grant No. 2010CB951702), Ministry of Water Resources Special Fund for Public Welfare Industry (Grant No. 201101047) and Chinese Academy of Sciences (Grant No. KZCX2-YW-310). We gratefully appreciated the anonymous reviewers for their critical comments on improving the original manuscript.

Edited by: H. Cloke

\section{References}

Alllan, R. J.: ENSO and climatic variability in the past 150 years, in: ENSO: Multi-scale Variability and Global and Regional Impacts, edited by: Diaz, H. F. and Markgraf, V., Cambridge University Press, Cambridge, 3-55, 2000.

Barton, S. B. and Ramírez, J. A.: Effects of El Niño Southern Oscillation and Pacific Interdecadal Oscillation on Water Supply in the Columbia River Basin, J. Water Res. Pl.-ASCE, 130(4), 281289, 2004.

Barnston, A. G. and Ropelewski, C. F.: Prediction of ENSO episodes using canonical correlation analysis, J. Climate, 7, 1316-1345, 1992.

Beebee, R. A. and Manga, M.: Variation in the relationship between snowmelt runoff in Oregon and ENSO and PDO, J. Am. Water Resour. Assoc., 40(4) 1011-1024, 2004.
Cane, M. A. and Dolan, S. C.: Experimental forecasts of El Niño, Nature, 321, 827-832, 1986.

Cayan, D. R., Redmond, K. T., and Riddle, L. G.: ENSO and hydrologic extremes in the western United States, J. Climate, 12(9), 2881-2893, 1999.

Chandimala, J. and Zubair, L.: Predictability of stream flow and rainfall based on ENSO for water resources management in Sri Lanka, J. Hydrol., 335(34) 303-312, 2007.

Chang, G., Li, L., Zhu, X., Wang, Z., Xiao, J. and Li, F.: Changes and Influencing Factors of Surface Water Resources in the Source Region of the Yellow River, Acta Geogr. Sin., 62(3), 312-320, 2007.

Chen, D., Zebiak, S. E., Busalacchi, A. J., and Cane, M. A.: An improved procedure for El Niño forecasting: Implications for predictability, Science, 269, 1699-1702, 1995.

Chiew, F. H. S. and McMahon, T. A.: Global ENSO-streamflow teleconnection, streamflow forecasting and interannual variability, Hydrolog. Sci. J., 47, 505-522, 2002.

Chiew, F. H. S., Piechota, T. C., Dracup, J. A., and McMahon, T. A.: El Niño/Southern Oscillation and Australian rainfall, streamflow and drought: links and potential for forecasting, Journal Hydrol., 204, 138-149, 1998.

Gutiérrez, F. and Dracup, J. A.: An analysis of the feasibility of long-range streamflow forecasting for Colombia using El NiñoSouthern Oscillation indicators, J. Hydrol., 246(1-4), 181-196, 2001.

Hamlet, A. F. and Lettenmaier, D. P.: Columbia River Streamflow Forecasting Based on ENSO and PDO Climate Signals, J. Water Res. Pl.-ASCE, 125(6), 333-341, 1999.

Jahan, N., Hasan Zobeyer, A. T. M., and Bhuiyan, M. A.: El Nino-Southern Oscillation (ENSO): recent evolution and possibilities for long range flow forecasting in the BrahamaputraJamuna River, Global Nest J., 8(3) 179-185, 2006.

Kahya, E. and Dracup, J. A.: U.S. Streamflow Patterns in Relation to the El Niño/Southern Oscillation, Water Resour. Res., 29(8), 2491-2503, 1993.

Kahya, E. and Dracup, J. A.: The influences of Type 1 El Niño and La Niña events on streamflows in the Pacific southwest of the United States, Journal Climate, 7(6), 965-976, 1994.

Kahya, E. and Karabork, M. C.: The analysis of El Niño and La Niña signals in streamflows of Turkey, Int. J. Climatol., 21(10) 1231-1250, 2001.

Karamouz, M. and Zahraie, B.: Seasonal Streamflow Forecasting using Snow Budget and El Niño-Southern Oscillation Climate Signals: Application to the Salt River Basin in Arizona, J. Hydrol. Eng., 9(6), 523-533, 2004.

Kazadi, S. N. and Kaoru, F.: Interannual and long-term climate variability over the Zaire River Basin during the last 30 years, J. Geophys. Res., 101(D16), 21351-21360, 1996.

Kiladis, G. N. and Diaz, H. F.: Global climatic anomalies associated with extremes in the Southern Oscillation, J. Climate, 2, 10691090, 1989.

Lan, Y., Ma, Q., Kang, E., Zhang, J., and Zhang, Z.: Relationship between ENSO Cycle and Abundant or Low Runoff in the Upper Yellow River, J. Desert Res., 22(3), 262-266, 2002.

Lan, Y., Ding, Y., Kang, E., Zhang, J., and Liu, G.: Change trends of the annual runoff in the upper Yellow River and time series Markov-Chain forecast model, J. Glaciol. Geocryol., 25(3), 321326, 2003. 
Liang, S., Xu, D., Wan, L., Chen, J., and Zhang, J.: Periodic regularity of the base flow in the headwater region of the Yellow river and affecting factors, Earth Sci. Front., 15(4), 280-289, 2008.

Marengo, J., Tomasella, J., and Uvo, C. R.: Long-term streamflow and rainfall fluctuations in tropical South America: Amazonia, Eastern Brazil and Northwest Peru, J. Geophys. Res., 103, 17751783, 1998

Piechota, T. C., Dracup, J. A., and Fovell, R. G.: Western US streamflow and atmospheric circulation patterns during El NinoSouthern Oscillation, J. Hydrol., 201(1-4), 249-271, 1997.

Press, W. H., Teukolosky, S. A., Vetterling, W. T., and Flannery, B. P.: Numerical Recipes in Fortran, Cambridge University Press, 963 pp., 1992.

Rasmusson, E. M. and Carpenter, T. H.: Variations in tropical sea surface temperature and surface wind fields associated with the Southern Oscillation/El Nino, Mon. Weather Rev., 110, 354-384, 1982.

Redmond, K. T. and Koch, R. W.: Surface climate and streamflow variability in the western United States and their relationship to large-scale circulation indices, Water Resour. Res., 27(9), 23812399, 1991.

Ropelewski, C. F. and Halpert, M. S.: North American precipitation and temperature patterns associated with the El Nino/Southern Oscillation (ENSO), Mon. Weather Rev., 114, 2352-2362, 1986.

Ropelewski, C. F. and Halpert, M. S.: Global and regional precipitation patterns associated with the El Nino/Southern Oscillation (ENSO), Mon. Weather Rev., 115, 1606-1626, 1987.

Ropelewski, C. F. and Halpert, M. S.: Precipitation patterns associated with high index phase of Southern Oscillation, J. Climate, 2, 268-284, 1989.

Shrestha, A. and Kostaschuk, R.: El Niño/Southern Oscillation (ENSO)-related variablity in mean-monthly streamflow in Nepal, J. Hydrol., 308(1-4), 33-49, 2005.
Simpson, H. J., Cane, M. A., Herczeg, A. L., Zebiak, S. E., and Simpson, J. H.: Annual river discharge in southeastern Australia related to El Niño-Southern Oscillation forecasts of sea surface temperatures, Water Resour. Res., 29(11), 3671-3680, 1993.

Troup, A. J.: The Southern Oscillation, Q. J. Roy. Meteorol. Soc., 91(390), 490-506, 1965.

Twine, T. E., Kucharik, C. J., and Foley, J. A.: Effects of El NiñoSouthern Oscillation on the Climate, Water Balance, and Streamflow of the Mississippi River Basin, J. Climate, 18(22), 48404861, 2005.

Wang, G., Shen, Y., and Liu, S.: On the Characteristics of Response of Precipitation and Runoff to the ENSO Events in the Source Regions of the Yellow River, J. Glaciol. Geocryol., 23(1), 16-21, 2001.

Wang, H., Yang, Z., Satio, Y., Liu, J. P., and Sun, X.: Interannual and seasonal variation of the Huanghe (Yellow River) water discharge over the past 50 years: Connections to impacts from ENSO events and dams, Global Planet. Change, 50(3-4), 212225, 2006.

Webster, P. J., Magaña, V. O., Palmer, T. N., Shukla, J., Tomas, R. A., Yanai, M., and Yasunari, T.: Monsoons: Processes, predictability, and the prospects for prediction, J. Geophys. Res., 103(C7), 14451-14510, 1998.

Whitaker, D. W., Wasimi, S. A., and Islam, S.: The El Niño Southern Oscillation and long-range forecasting of flows in the Ganges, International J. Climatol., 21(3), 77-87, 2011.

Zubair, L. and Chandimala, J.: Epochal Changes in ENSOstreamflow relations in Sri Lanka, J. Hydrometeorol., 7(6), 1237-1246, 2006. 